\title{
The Role Of The People In First Amendment Theory
}

\author{
Frederick Schauer $\uparrow$
}

History is what we make of it. Although there is undemiably a core of hard fact in any historical event, the contemporary significance of a past occurrence turns largely on a series of cultural choices made subsequent to the original happening. Which facts will a society eniphasize, and which will it ignore? What words will be used to describe those facts? With what other events will this event be descriptively and normatively assimilated? What theory or primciple or concept will this event be taken to exemplify? All of these questions are questions of characterization, and each characterization is a choice that will determine the present perception of a past event, often as much as what actually occurred.

I begin with these general observations about the nature of history because the question of the subsequent characterization of a historical event is nowhere more obvious than with respect to the trial 250 years ago of John Peter Zenger. ${ }^{1}$ A commonly accepted characterization of the event and its significance is as follows: Zenger was a conparatively mimor meniber of a group that criticized Governor William Cosby's regime of the Province of New York. Zenger primted criticisms of Cosby in the New York Weekly Journal, created primarily for the purpose of attacking Cosby. As publisher of this criticism of government, Zenger was prosecuted for the common law crime of seditious hibel. Largely as a result of the powerful advocacy of his lawyer, Andrew Hamilton, the

$\dagger$ Professor of Law, University of Michigan.

A version of this Article was presented in October, 1985 at a symposium honoring the 250 th anniversary of the trial of John Peter Zenger sponsored by the University of Pennsylvania Law School, the Philadelphia Bar Association, and the Annenberg School of Communications of the University of Pennsylvania. I am especially grateful to my commentators on that occasion, Vincent Blasi and Diana Daniels, as well as to Cass Sunstein, whose characteristically penetrating comments on the manuscript have improved it immeasurably.

1. The trial is reported as The Trial of Mr. John Peter Zenger (1735), 17 Howell's St. Trials 675 (1816). The most comprehensive contemporaneous account is largely the product of Zenger's original lawyer, James Alexander, and the most authoritative version is J. ALEXANDER, A BRIEF Narrative of the Case and Trial of John Peter Zenger, Printer of the New York WEekLy Journal (S. Katz ed. 1963). Other versions of the Brief Narrative, also with extensive commentary, are found in L. RUTherford, John Peter Zenger: His Press, His Trial aNd a Bibliography of Zenger Imprints (1941); The Trial of Peter Zenger (V. Buranelli ed. 1957). Another contemporary account is The Trial of John Peter Zenger, of New YoRK, Printer (J. Almon pub., London 1765), reprinted in The TRIAL of John Peter Zenger (1734) ANd The Freedom of the Press (P. Radin ed. 1940). 
jury acquitted Zenger. Because the jury acquittal was contrary to the law of seditious libel, its action is considered an important milestone for the principle that criticism of government and its officials is fundamental to a free society, notwithstanding the law of seditious libel. This common contemporary characterization focuses on Zenger as critic, on the oppressiveness of the common law of seditious libel, and on the victory of Zenger as critic over the King and the law of seditious libel.

Let us, however, examine more closely the legal background of the Zenger trial, for by doing so we obtam a slightly different perspective. At the time of the trial in 1735, the common law crime of seditious libel consisted of: (1) the intentional (2) publication of a (3) written (4) blame of any public man, or of the law, or of any institution established by law (5) without lawful excuse or justification. ${ }^{2}$ Application of this standard to the conduct of a particular defendant involved first determining the primarily factual issues of whether the defendant published the particular writimg at issue and whether he intended to publish it. Then ordinarily followed the question of innuendo, the interpretive issue of whether the words had the defamatory meaning alleged by the prosecution. In most cases the question of innuendo was limited to whether the publication referred to the alleged subject of the hibel. ${ }^{3}$ Finally there were the legal questions, although they were what might now be called mixed questions of law and fact. One of these questions, only occasionally at issue, was whether the defendant had the requisite criminal intent. More significant, and more commonly at the center of a seditious libel prosecution, was the question of whether the words containing the particular innuendo constituted a libel. At the time of the Zenger trial, the task of determining the purely factual and interpretive issues was for the jury. Determining the hibelousness of the publication, however, was treated as a question of law, for resolution not by the jury but by the judge. ${ }^{4}$ Since

2. Because seditious libel was not a statutory crime, either in Eugland or in the colonies, there is no authoritative statement of the elements of the offense. This definition was extracted from a number of sources. See The Trial of William Owen (1752), 18 Howell's St. Trials 1203 (1816); T. Green, Verdict according to Conscience: Perspectives on the ENGlish Criminal Trial Jury, 1200-1800 318-55 (1985); L. LeVY, EMergence of A Free Press 3-15 (1985); L.

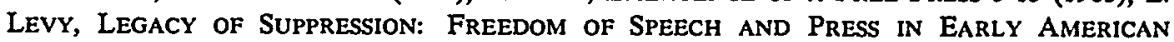
History 1-18 (1960); Katz, Introduction to J. Alexander, A Brief NarRative of THe Case ANd TRIAL OF JohN Peter ZeNger 1 (S. Katz ed. 1963); Levy, Introduction to Freedom of THE PRESS FROM ZENGER TO JeFFERSON xix (L. Levy ed. 1966); Hamburger, The Development of the Law of Seditious Libel and the Control of the Press, 37 STAN. L. REv. 661, 700-08 (1985); Mayton, Seditious Libel and the Lost Guarantee of a Freedom of Expression, 84 CoLUM. L. REv. 91, 102-08 (1984).

3. For an example of a case in which this issue was contested, see Trial of Richard Francklin (1731), 17 Howell's St. Trials 626 (1816).

4. The state of the law on this point was articulated clearly by Lord Chief Justice Raymond in Francklin's Case in 1731:

In this information [f]or libel, there are three things to be considered, whereof two by you 
Zenger contested neither innuendo nor publication, the jury was obliged under common law to convict; it had no legal authority to consider whether this publication was seditious, and its role, in a case such as this, was strictly a formality. Thus, the jury's verdict nullified the law or, at the very least, usurped the judicial function as it was understood at the time. $^{5}$

Looking at the Zenger case in this hight yields quite a different characterization. The case now appears as a victory for the jury over the judge, and in a larger sense a victory for the people as represented by the jury over the King as represented by the judge. Zenger's case is inerely one of inany instances in which the defendant's responsibility for the physical act of publication was not subject to dispute. Similarly, questions of the identity of the person referred to in a publication usually had an obvious answer. Thus, determining whether certain words were libelous was of crucial and usually dispositive inportance in any libel action. Whoever determined this issue had the greater decisional power in a seditious libel case. If the judge determined libelousness, then the role of the jury was inconsequential, limited to the resolution of rarely disputed factual questions. But if the jury determined libelousness, then it could linnt the use of seditious hibel prosecutions by those in power. The Zenger jury, by ignoring Justice de Lancey's instructions and the law, took a stand in favor of the latter approach and in favor of greater

\footnotetext{
the jury, and one by the Court. The first thing under your consideration is, Whether the defendant, Mr. Francklin, is guilty of the publication of this Craftsman or not? The second is, Whether the expressions in that letter refer to his present majesty and his principal officers and ministers of state, and are applicable to them or not? This is the chief thing in the information; for if you think that these defamatory expressions are not applicable to them, then the defendant is not guilty of what is charged upon him; but if you think that they are applicable to them, then the defendant is guilty thereof; upon this supposition, that you find him to be the publisher of that paper. These are the two matters of fact that come under your consideration; and of which you are proper judges. But then there is a third thing, to wit, Whether these defamatory expressions amount to a libel or not? This does not belong to the office of the jury, but to the office of the Court; because it is a matter of law, and not of fact; and of which the Court are the only proper judges.
}

Trial of Richard Franklin (1731), 17 Howell's St. Trials 626, 671-72 (1816); see also Trial of the Dean of St. Asaph (1783), 21 Howell's St. Trials 847, 1038-39 (1816) (Mansfield, J.).

Despite Andrew Hamilton's pleas on behalf of Zenger that truth should be available as a defense, that the law in New York need not be the same as the law in England, and that the jury should consider the question of libelousness, Justice de Lancey adhered to the prevailing law of sedititious libel. Trial of John Peter Zenger (1735), 17 Howell's St. Trials 675, 699, 703, 706, 722-23 (1816). The Zenger jury was thus instructed according to the division of responsibility articulated in Francklin's Case and many others of the time. See, e.g., Trial of the Dean of St. Asaph (1783), 21 Howell's St. Trials 848, 1038-39 (1816); Trial of William Owen (1752), 18 Howell's St. Trials 1203, 1228-30 (1816). For descriptions of the general state of the law at the time on the division of responsibility between judge and jury, see T. GREEN, supra note 2, at 253-55, 278-85; 8 W. HOLDSWORTH, A History of English Law 343 (1926); 2 J. Stephen, A History of the Criminal Law of ENGLAND 298-300 (1883).

5. For a similar example of jury acquittal in the face of a clear legal obligation on the jury's part to convict, see the Trial of William Owen (1752), 18 Howell's St. Trials 1203 (1816). 
power for the jury. Under this alternative characterization of the Zenger case, control by the people rather than by the monarchy emerges as central, ${ }^{6}$ and it is impossible to separate the free speech/free press questions from the questions of the power of the people to decide their own destiny.

This characterization of the Zenger trial as about jury and popular power is more than just a view from 250 years later. It was one commonly held at the time. ${ }^{7}$ Throughout most of the eighteenth century, the questions of freedom of the press, the scope of the common law crime of seditious hbel, and the possibility for an increased role for the jury in seditious hibel cases were frequently treated as inseparable. ${ }^{8}$ From the time of the Seven Bishops ${ }^{9}$ case in 1688, it was commonly argued that increasing jury power to determine seditiousness and intent would advance freedom of the press. ${ }^{10}$ Fox's Libel Act, passed in $1792,{ }^{11}$ constituted a great victory for freedom of the press precisely because it gave the jury power to issue a general verdict, which entailed the consequent power to reject a judicial determination of seditiousness. ${ }^{12}$

My goal is not to provide a definitive characterization of the Zenger trial or of early free speech doctrime. But identifying a characterization different from that commonly employed allows us to draw different lessons from historical events. If we focus on the role of the jury rather than on the fact of Zenger's acquittal, a different array of issues is before us. What makes these issues important is the strikingly different view of the relationship between jury power and free speech that now holds sway.

6. Implicit in this is the assumption, prevalent at the time, that judges were more likely to side with the monarchy than with people who opposed that institution. See T. GREEN, supra note 2, at 249-55, 334, 340-42. That judicial sympathy with the Crown was a dominant concern explains why, almost fifty years after Zenger, Lord Mansfield took pains to note that "[t]he judges are totally independent of the ministers that may happen to be, and of the king himself. Their temptation is rather to the popularity of the day." Dean of St. Asaph's Case (1783), 21 Howell's St. Trials 848, 1040 (1816).

7. See T. GREEN, supra note 2, at 252, 322-23; Katz, supra note 2, at 15-16. On the relationship between seditious libel trials and perceptions of popular sovereignty, see Rabban, The Ahistorical Historian: Leonard Levy on Freedom of Expression in Early American History (Book Review) 37 STAN. L. REV. 795, 823-27 (1985).

8. In this sense, expansion of the role of the jury was taken as a libertarian position, although the libertarian position did not call for total rejection of the crime of seditious libel. See Rabban, supra note 7 , at 819-20, 824-27.

9. 12 Howell's St. Trials 183 (1688).

10. A good example is the series of letters by James Alexander, which can be found in Freedom of THE PRess from Zenger to Jefferson, supra note 2, at 61-74.

11. 32 George 3, ch. 60 .

12. See T. GREEN, supra note 2, at 330-31, 349-50; 10 W. HolDSWORTH, supra note 4, at 672 74. This is not to say that Fox's Libel Act produced as much in the way of freedom of press as was initially hoped. See Levy, Introduction, Freedom of THE Press From Zenger to Jefferson, supra note 2 , at xix, xxxiii. 
Not only at the time of the Zenger trial, but also up to and even past the adoption of the first amendment, the jury was seen as the primary protector of free speech. ${ }^{13}$ Although juries by no means acquitted with great frequency after the Zenger case or even after Fox's Libel Act, the jury's increased role in libel cases was seen as among the central principles of freedom of speech and freedom of the press. Free speech existed largely in the extent to which the people-througl their surrogate, the jury-could decide how much the mdividual could criticize the government. ${ }^{14}$ Undemiably, a significant aspect of eighteenth century free speech doctrine was how much could be said. But an equally significant aspect was whether the people, rather than a nonrepresentative government, should determine how much could be said. What emerges from looking at the history is the conclusion that much of the history of free speech thinking in the eighteenth century is a history of promoting free speech by promoting the power of the jury.

Today, im sharp contrast, the tables have turned. We no longer view juries as primary or even important protectors of free speech. On the contrary, much of contemporary first amendment doctrine, theory, and commentary is devoted to protecting speech from the jury. Where 250 years ago, more jury power was taken as comcident witli greater freedom of speech, more jury power now is taken as just the opposite. The role of juries, involved in a wide range of cases with free speech implications, is a recurrent issue in areas such as defamation, ${ }^{15}$ speech by public einployees, ${ }^{16}$ obscenty,${ }^{17}$ mvasion of privacy, ${ }^{18}$ and incitement. ${ }^{19}$ The common wisdom is that if juries were given more decisional power in these areas, either by increasing the range of issues they could consider or by granting juries greater immunty from appellate review, free speech would suffer a crippling blow.

The contemporary distrust of juries has numerous manifestations. A long hine of cases, culminating for the moment with Bose Corp. v. Consumers Union of United States, ${ }^{20}$ has increased the power and obligation of appellate courts to review juries' factual determinations about activity

13. See T. GREEN, supra note 2, at 341, 353; Levy, The Legacy Reexamined, 37 STAN. L. REv. 767, 792 (1985).

14. See Parker, Free Expression and the Function of the Jury, 65 B.U.L. REV. 483, 503 (1985).

15. E.g., Bose Corp. v. Consumers Union of United States, 466 U.S. 485, 510-11 (1984); New York Times Co. v. Sullivan, 376 U.S. 254, 283-85 (1964).

16. See Parker, supra note 14, at 510-38.

17. E.g., Jenkins v. Georgia, 418 U.S. 153, 160 (1974); Miller v. California, 413 U.S. 15, 29-30 (1973); Jacobellis v. Ohio, 378 U.S. 184, 188 (1964) (plurality opinion of Brennan, J.).

18. Virgil v. Time, Inc., 527 F.2d 1122 (9th Cir. 1975), cert. denied, 425 U.S. 998 (1976); see also Parker, supra note 14 , at 506-08.

19. Hess v. Indiana, 414 U.S. 105, 109-12 (1973) (per curiam) (Rehnquist, J., dissenting).

20. 466 U.S. 485 (1984). For a powerful critique of Bose, see Monaghan, Constitutional Fact Review, 85 Colum. L. Rev. 229 (1985). 
that, depending on the jury's verdict, may fall within the protection of the first amendment. ${ }^{21}$ This obligation of independent appellate factual review extends not only to the determination of malice at issue in Bose, but also to the question, strongly remimiscent of Zenger, whether a given publication can be considered defamatory at all. ${ }^{22}$ Similarly, appellate courts routinely evaluate materials found obscene by juries against an imdependent standard of constitutionality. ${ }^{23}$ Likewise, questions of imminence and likelihood in the application of Brandenburg v. Ohio ${ }^{24}$ are not left even to properly instructed juries, but, as Hess $v$. Indiana ${ }^{25}$ teaches us, remam subject to judicial scrutiny.

The distrust of juries is also evident in the initial avoidance of jury determinations. Strong free speech proponents insistently call for a greater use of summary judgment and similar trial-avoiding devices in defamation cases. $^{26}$ The right to jury trial is waived with remarkable frequency by those wishing to invoke free speech claims in defense of their activities. ${ }^{27}$ Perhaps most pervasively, the progressive rejection of what is commonly and simplistically known as an "ad hoc balancing" approach to the first amendment has served to limit the number of factual and contextual variables that may be considered in an individual case. $^{28}$ This narrowing of variables is based in part on a distrust of particularized decisionmaking in cases touching on the first amendment, a

21. For a post-Bose discussion and application of this power, see Tavoulareas v. Piro, 759 F.2d 90, 105-09, reh'g denied and reh'g en banc granted, 763 F.2d 1472, 1479-80 (D.C. Cir. 1985).

22. Indeed, the Supreme Court exercised such power in New York Times Co. v. Sullivan, 376 U.S. 254 (1964), insofar as the Court reaclied its own judgment that the particular publication could not constitutionally be sanctioned even by a properly instructed jury. Further examples of this independent factual review are provided by Old Dominion Branch No. 496 v. Austin, 418 U.S. 264, 280-87(1974) and Greenbelt Coop. Publishing Ass'n v. Bresler, 398 U.S. 6, 14 (1970).

23. See Jenkins v. Georgia, 418 U.S. 153, 160 (1974); Miller v. California, 413 U.S. 15, 29-30 (1973); Jacobellis v. Oliio, 378 U.S. 184, 188 (1964) (plurality opinion of Brennan, J.); Manual Enterprises, Inc. v. Day, 370 U.S. 478, 488 (1962) (plurality opinion of Harlan, J.); Kingsley Int'l Pictures Corp. v. Regents of N.Y., 360 U.S. 684, 708 (1959) (Harlan, J., concurring).

24. 395 U.S. 444 (1969) (per curiam).

25. 414 U.S. 105, 107-09 (1973). The Court also indicated its willingness to review jury verdicts in Fiske v. Kansas, 274 U.S. 380 (1927).

26. See, e.g., Anderson, Libel and Press Self-Censorship, 53 TEx. L. REv. 422, $435-38$ (1975); Levine, Judge and Jury in the Law of Defamation: Putting the Horse Behind the Cart, 35 AM. U. L. REv. 3 (1985); Rendleman, Chapters of the Civil Jury, 65 KY. L.J. 769, 778-87 (1977). The Supreme Court seems to have resolved the issue, albeit not on first amendment grounds. Anderson v. Liberty Lobby, Inc., 106 S. Ct. 2505 (1986). I recognize, of course, that part of this concern is to eliminate the expense of lengthy litigation in cases in which the implausibility of the plaintiff's claim is clear from the outset. These concerns with expense are admittedly unrelated to the concerns revolving around fears of the jury.

27. I rely here not on any statistical studies, but on my personal experiences some years ago as defense counsel in obscenity cases.

28. I discuss this issue at greater length in Schauer, Categories and the First Ainendinent: A Play in Three Acts, 34 VAND. L. Rev. 265, 296-305 (1981). 
distrust that is not limited to jury decisionmaking but which certainly includes it.

In hight of this distrust of juries, it is not surprising that the availability of a jury trial currently does little to allay the fears of the organized press. Recent defamation cases provide a good illustration. Defamation actions brought by Ariel Sharon against Time Magazine, ${ }^{29}$ William Westmoreland agamst CBS, ${ }^{30}$ John Lakian against the Boston Globe, ${ }^{31}$ Carol Burnett against the National Enquirer, ${ }^{32}$ William Shockley against the Atlanta Constitution, ${ }^{33}$ William Tavoulareas against tlie Washington Post, ${ }^{34}$ and many others of less notoriety have caused great concern within the press. Altliough the press undoubtedly has its own particular interest in guarding against a proliferation of libel suits, this concern is sliared by many otlers who are not theinselves members of the institutional press. Yet $\mathrm{m}$ some sense this concern is puzzling. In every one of these cases the defendant had the right to a jury determination of the issues in the case, and in every one of these cases the jury would liave, at trial, the power to find for the press defendant and against the libel plaintiff. At the time of the Zenger trial, this access to jury determination of the issues would have alleviated concerns about the freedom of the press because the determination was being made by the people rather than an unaccountable sovereign. And this would liave been sufficient to alleviate inost of the concerns that were then expressed with free speecli/free press rubric. Now, however, the presence of the jury is not seen as the safeguard it was in 1735 and in 1791 . Today, despite the presence of the jury, or perhaps because of it, many perceive the freedoin of speech and press to be in jeopardy, with the principle of free criticism of government hanging by a thread. ${ }^{35}$ What lias caused this cliange? Why is freedom of speecll, once ahgned with the jury, now taken to require protection from

29. Sharon v. Time, Inc., 599 F. Supp. 538 (S.D.N.Y. 1984); Sharon v. Time, Inc., 575 F. Supp. 1162 (S.D.N.Y. 1983).

30. Westmoreland v. CBS, 601 F. Supp. 66 (S.D.N.Y. 1984); Westmoreland v. CBS, 596 F. Supp. 1170 (S.D.N.Y. 1984).

31. There is no reported opinion. For an account of the litigation, see Nat'1 L. J., Aug. 26, 1985, at 45, col. 1; Nat'l L. J., Aug. 19, 1985, at 34, col. 1.

32. Burnett v. Nat'1 Enquirer, 144 Cal. App. 3d 991, 193 Cal. Rptr. 206 (1983).

33. There is no reported opinion. For an account of the litigation, see Nat'1 L. J., Oct. 1, 1984, at 8, col. 1; Hirsley, The Testing of a Theory About Race, Nat'1 L. J., Sept. 24, 1984, at 6, col. 1.

34. Tavoulareas v. Piro, 759 F.2d 90, reh'g denied and reh'g en banc granted, 763 F.2d 1472 (D.C. Cir. 1985).

35. The following is only a minuscule sample of published expressions of this theme. See, e.g., Smolla, Let the Author Beware: The Rejuvenation of the American Law of Libel, 132 U. PA. L. REv. 1 (1983); Nat'1 L. J., July 8, 1985, at 5, col. 1; id., Mar. 4, 1985, at 3, col. 1; Abrams, Why Our Outdated Libel Laws Are in Desperate Need of Reform, L.A. Daily J., Sep. 30, 1985, at 4, col. 3; Clurman, Journalism Lost, L. A. Daily J., Jan. 31, 1984, at 4, col. 3; Garbus, Change the Libel Laws, L.A. Daily J., Aug. 3, 1983, at 4, col. 3; Garbus, New Challenge to Press Freedom, N.Y. Times, Jan. 29, 1984, sec. 6 (Magazine), at 34; Lewis and Schrag, The Press as First-Draft Historian, L.A. Daily J., Jan. 9, 1985, at 4, col. 3; McHugh, Costs of Libel Defense "Chill" the Media, Chicago Daily L. B. 
jury power? ${ }^{36}$

This change in perceptions of the relationship between juries and free speech seems to reflect a larger concern about popular control. The jury has always been perceived as a practical surrogate for popular decisionmaking in a world in which it is impossible to put questions of individual habihty or culpability to electoral referenda. ${ }^{37}$ In theory, the views of the jury reflect the views of the population at large, ${ }^{38}$ and there seems little doubt that the views of conteinporary juries in cases involving the claims of public officials and public figures against the press are in fact a roughly accurate mirror of the views of the population. Those who fear juries would, therefore, probably also fear other popular decisionmaking processes affecting free speech/free press issues. For exainple, those who distrust juries to resolve the dispute between General Westmoreland and CBS would, I suspect, equally distrust the public to decide, in a national referendum, the relative merits of the claims of defamed public figures and major national media in general. I would guess that Ariel Sharon's popularity increased rather than decreased because he was willing to sue Time for libel. And this is so despite the public's ample access to the point of view that libel actions brought by public officials against the media are a threat to one of our most cherished liberties.

This aversion to jury power leads us to the larger issue: What conception of freedom of speech and press would produce a system in which an informed public would not be allowed to decide just how inucl speech it wanted? There are some easy answers to this question, but, as shall be seen, they are too easy. Reflexive incantation from de Tocqueville ${ }^{39}$ or Mill ${ }^{40}$ of the phrase "tyramiy of the majority" is not likely to be helpful, and is least helpful when the notion of tyranny of the majority is invoked witll reference to theories of free speech that, in turn, rely on popular control of government. My goal, therefore, is to look closely at the relationship between popular control and the underlying justifications for a theory of free speech, to show that we may liave too easily abandoned one of the legacies of John Peter Zenger-that popular restriction of speaking is a consequence of a different and lesser order than restriction

Dec. 11, 1985, at 1, col. 2; Winter, ACLU on Libel: A Switch to Defendants' Side, 69 A.B.A.J. 729 (1983); Flaherty, The Law's Literary Life, Nat'1 L. J., Apr. 2, 1984, at 1, col. 1.

36. In addition to the authorities cited supra note 35 , see in particular N.Y. Times, May 5, 1983, at B15, col. 1 .

37. On this role of the jury, see P. Devlin, Trial By JuRY 160-62 (1956); T. GreEN, supra note 2, L. MOORE, THE JURY 182 (1973); Scheflin \& Van Dyke, Jury Nullification: The Contours of a Controversy, 43 LAw \& Contemp. Probs. 51 (Autumn 1980).

38. I am referring here to the fact that recent legislative and constitutional developments have removed most of the wholesale exclusions, such as those based on race, sex, and property ownership, that would cast doubts on claims of jury representation of popular views.

39. 1 A. De TocQueville, Democracy in America 263-87 (P. Bradley ed. 1945).

40. J.S. Mill, ON Liberty 6-10 (D. Spitz ed. 1975). 
of speaking by agents neither representative of nor accountable to the public.

I want to commence the analysis by drawing on a now commonplace distinction in moral philosophy-the distinction between utilitarian/consequentialist perspectives and deontological perspectives. ${ }^{41}$ Although this is hardly the place to explore fully these competing positions, a simplified examination of the two views will serve my purpose. The consequentialist evaluates past or contemplated actions in terms of the consequences those actions did or are likely to produce. If those consequences are in turn evaluated with reference to the general public interest, the net result is that courses of action are measured against a standard of whether their consequences advance the public interest. Because the idea of "the pubhic interest" is complex and elusive, ${ }^{42}$ I want to steer well clear of disputes about the meaning of the term and use "public interest" as shorthand for a general consequentialist/utilitarian perspective that focuses on maximizing the aggregate welfare of the people. This simple description undemably abbreviates nearly 200 years of moral philosophy im the utilitarian tradition-from Bentham to the present-but still, it captures the point I want to stress: that a utilitarian/ consequentialist perspective employs as its standard of evaluation some calculus designed to determine what is best for the population as a whole.

In contrast to utilitarian/consequentialist perspectives, a deontological outlook focuses on the inherent rightness or wrongness of particular actions, regardless of the consequences those actions might produce. ${ }^{43}$ For example, torture is simply wrong, regardless of its effect on society. Charity imight be imtrinsically good even when it produces consequences ultimately detrimental to the public interest. People have a right to equal concern and respect even if granting that right detracts from the public welfare. ${ }^{44}$ These examples typify a Kantian legacy that looks to the intrinsic quality of an action rather than to its consequences as the measure of that action. Under a deontological theory, although we inay

41. A good introduction to the distinction is J.J.C. SMART \& B. WILL1AMS, UTILITARIANISM: For AND AgAinst (1973). For a critique, see Piper, $A$ Distinction Without Difference, 7 MIDWEST STUD. PHIL. 403 (1982).

42. See Barry, The Public Interest, in Political Philosophy 112 (A. Quinton ed. 1967); Benditt, The Public Interest, 2 PHIL. \& PuB. AfF. 291 (1973); Diggs, The Common Good as Reason for Political Action, 83 Ethics 283 (1973). See generally, NOMOS V: THe PUBlic INTERest (C. Friedrich ed. 1962).

43. For a clear and succinct analysis of the differences between consequentialist and nonconsequentialist reasoning, see Miller, Rights or Consequences, 7 MidwEST STUD. PHIL. 151 (1982).

44. R. Dworkin, A Matter of Principle 196-97 (1985); R. Dworkin, Taking Rights SERIOUSLY 272-78 (1977) [hereinafter R. DWORKIN, RIGHTS]. 
sometimes look to consequences or to the public interest, these inquiries can never exhaust the analysis. Some acts might be valued even if in valuing them we detract from what is best for the population as a whole, and other acts might be condemned even if in condemning them we again fall short of optimizmg the public welfare.

I distinguish deontological and utilitarian/consequentialist theories in order to relate the values underlying a theory to the locus of decisionmaking concerning the defimition and application of those values. Putting aside the specific value of free speech for the moinent, it seeins plausible to suppose that popular decisionmaking might be treated as especially important with respect to utihtarian/consequentialist values. If an action is to be evaluated based on whether it is in the public interest, or because it would benefit the population, then it does not seem odd that any population, or any public whose interest is at stake, would have some say in the matter. By no means does this follow inexorably. Government for the people does not logically entail government by the people. If we assume, perhaps justifiably, that people might not know what is best for them, then the ideal social structure, even under a consequentialist/utilitarian principle, might avoid any form of democratic or Inajoritarian decisionmaking. But there are sufficient practical problems with even utilitarian dictatorships or philosopher-kings that I feel relatively safe in suggesting that a pohtical theory that requires maximizing the pubhic interest presents a strong argument for popular input into or control over governmental decisions. I do not mean for this to be the end of the analysis. Things are far more complex than this. But I do begin with the intuitive proposition that in determining what is in the public interest, we might be interested in consulting the public.

The connection between utihtarian consequentialism and popular decisionmaking is strongest if we rely on the more hedonistic versions of utilitarianism premised on the wants of the people. ${ }^{45}$ Theories of the public interest are hkely to avoid the hedonistic trap, recognizing that there is at least some space between what people want and what is best for them. Here the focus would be on the needs or justified desires of the people ${ }^{46}$ and on the belief that inerely because the people want something does not inean that they ought to get it. Yet even theories of utilitarianism based on the needs rather than the wants of the people appear to provide some support for pervasive public input into the decisionmaking process. If the point of reference is what is best for the people, and if

45. For a brief explanation of this form of subdividing utilitarianism, see D. PARFIT, REASONS AND PERSONS 493-502 (1984). The contrast between what is good for a person and that person's preferences is pervasive in most contemporary discussions of utlitarianism. See, e.g., UTilitaRianism AND Beyond (A. Sen \& B. Williams eds. 1982).

46. See D. PARFIr, supra note 45 , at 499-501. 
there are demonstrable dangers in assuming that this determination can be made solely in the people's mterest by rulers not accountable to those people, then concern for the public interest may very well entail an interest in what the public has to say about the inatter.

From the deontological perspective, however, the pull towards representative or popular decisioninaking is reduced. If torture is wrong regardless of whether it serves the public interest, then it is unnecessary to consult the public on the torture question. If it is wrong for a government to exterminate Jews or gypsies, then it does not become right even if that act improves the lives of everyone remaining, nor does it become right even if it is approved in free and open elections. The inherent moral quality of slavery cannot be measured by the benefit it bestowed on the quality of life in Alabama in 1848. From a deontological perspective, the fact that Alabamians approved of slavery in 1848 is scarcely relevant.

Much of free speech theory can be located within this philosophical division. If speaking freely is a "natural right," speaking ought to be protected by a properly constituted state regardless of whether it is in the public interest to do so. If it is wrong for the state to prevent me from speaking for the same reason that it is wrong for the state to torture ine, then the public interest ought not to enter into the calculation. This suggests a different conclusion with respect to public decisionmaking. If, deontologically, it is simply wrong to keep me froin speaking, then there is no reason to think that popular decisionmaking, whether by a jury or by a legislature, ought to enter imto the process. Thus, if the first amendinent is simply the formal constitutional protection of an inherent human right, then liinitations on jury and legislative power make perfect sense. Indeed, if we expect that protecting the right will often entail sacrifices of the public interest, then good reasons emerge for withdrawing public control even if such control otherwise exists within a society. For under sucli a deontological outlook, we protect speech not necessarily because it is in the public interest to do so. Rather, we protect speech despite the fact that it may be in the public interest not to do so. ${ }^{48}$

Free speech theories based on the deontological perspective liave been with us for some time. They are often parts of larger theories that may include utilitarian/consequentialist elements. ${ }^{49}$ At times they provide, for some thinkers, virtually all that is necessary to support a strong

47. I will use the terms "natural rights" and "human rights" to refer to deontological theories of individual rights. The terms are crude, and the questions of human rights in a complex world are difficult, but I do not want to stray too far afield. For a sampling of the literature, see J. FINNIS, Natural Law and Natural Rights (1980); A. Gewirth, Human Rights (1982); HumaN RIGHTS (E. Kamenka \& A. Tay eds. 1978); Rights (D. Lyons ed. 1979).

48. See R. DWORKIN, RIGHTS, supra note 44, at 190-95.

49. See, e.g., T. EMERSON, THE SYSTEM OF FrEEDOM OF EXPRESSION 6-9 (1970). 
right to freedom of speech. ${ }^{50}$ Usually these theories are couched in terms of self-expression, self-reahzation, or self-fulfillment, but the core idea is the same-speaking is part of what it is to be a person, and restrictions on that expression of personhood by the state are simply wrong, even if the public interest would be served by those restrictions.

Deontological theories of free speech stressing self-fulfillment, selfrealization, or self-expression draw their appeal from the undeniable attractiveness of some degree of personal hiberty. But the grounding in concepts of personal hiberty is precisely the undoing of these theories. ${ }^{51}$ Self-expression theories founder because they do not distinguish speaking from a wide range of other self-expressive activities that fall outside the purview of the first annendment. A satisfactory theory of free speech must explain not only why speech is distinguishable from other distinctly human self-expressive activities, such as riding a motorcycle or appearing naked in public, but also why speech needs more protection than activities that are not necessarily distinctly humnan but which are rather more important than speaking out when you wish, such as food and shelter. ${ }^{52}$

Even more significantly, self-expression theories do not provide a reason for protecting those self-expressive activities that can cause harm to others. General theories of personal liberty invariably incorporate the principle that personal liberty can be restricted in those instances when the exercise of that liberty causes harm to others. If we assume that the first ainendinent now protects, or ought to protect, all acts that cause no demonstrable harm to others, we are unable to explain the protection of acts that do in fact cause harm to others, such as defamatory statements, acerbic book reviews, critical evaluations of restaurants and newly opened plays, public racial epithets, or revelations (true or false) about a political candidate's past. In all of these cases, self-expression can cause

50. See, e.g., R. DWORKIN, Rights, supra note 44; M. REDISH, FrEEdom of EXPREsSION: A CRITICAL ANALYSIS (1984); Baker, Realizing Self-Realization: Corporate Political Expenditures and Redish's The Value of Free Speech, 130 U. PA. L. REv. 646 (1982)[hereinafter Baker, Realizing SelfRealization]; Baker, Scope of the First Amendment Freedom of Speech, 25 UCLA L. REv. 964 (1978); Redish, The Value of Free Speech, 130 U. PA. L. Rev. 591 (1982); Richards, Free Speech and Obscenity Law: Toward a Moral Theory of the First Amendment, 123 U. PA. L. REV. 45 (1974).

51. The conclusions offered here are little more than a summary of more extended arguments I have made elsewhere. See F. SchaUer, Free SpEech: A PhILosophICAl EnQUiRY 47.72 (1982); Schauer, Must Speech Be Special?, 78 Nw. U.L. REv. 1284 (1983); Schauer, Speech and "Speech" Obscenity and "Obscenity": An Exercise in the Interpretation of Constitutional Language, 67 GEO. L.J. 899 (1979); see also Levinson, First Amendment, Freedom of Speech, Freedom of Expression: Does It Matter What We Call It?: A Review Of Freedom of Expression: A Critical Analysis, 80 Nw. U.L. REv. 767 (1985).

52. I defend this proposition in Schauer, Must Speech Be Special?, supra note 51; see also Bork, Neutral Principles and Some First Amendment Problems, 47 IND. L.J. 1, 25 (1971). For opposing views, see Greenawalt, Speech and Crime, 1980 AM. B. Found. Res. J. 645, 734 n.344; Perry, Freedom of Expression: An Essay on Theory and Doctrine, 78 Nw. U.L. Rev. 1137, 1154 (1983); Redish, supra note 50; Shiffrin, The First Amendment and Economic Rcgulation: Away From a General Theory of the First Amendment, 78 Nw. U.L. REv. 1212, 1238-39 (1983). 
the very types of harms that are generally taken to justify governmental intervention. Thus, a plausible natural-rights theory of free speech based on hiberty of self-expression must contain an exception allowing restriction when harm is caused. Such theories are at a loss, however, to explain why we protect harm-producing speech. For that we must look elsewhere.

Moreover, deontological self-expression theories are difficult to reconcile with conteinporary first amendment doctrine, which does not treat all forins of human speech equally. Self-expression theories evaluate freeness of speech in terins of the huinan needs of some human being. Under such a theory it would no longer be clear ${ }^{53}$ that speech by corporations imphcates the protections of free speech, ${ }^{54}$ even if those corporations are primarily or exclusively in the business of communicating. ${ }^{55}$ Nor would it remam clear that speech with respect to inatters of politics, or public concern, or public affairs, or whatever characterization of this idea is chosen, has some special place in the first amendment pantheon. If we want to protect the natural human right to communicate regardless of the consequences of that communication to the public interest, then it is no longer apparent that the interests of the New York Times Company in publishing The Pentagon Papers ${ }^{56}$ are any stronger than the interests of the average citizen in urging his friends to see the beauty and truth of astrology. As a theoretical matter, this possibility-treating corporate speakers on political matters as identical for all first amendnient purposes with individual speakers on personal matters-might be quite plausible, but it is becoming increasingly remote from conteniporary doctrine. Conteinporary doctrine may of course be wrong. Still, the relationship between first aniendment theory and first aniendment adjudication ideally involves a reasoning process similar to a Rawlsian reflective equilibrium. ${ }^{57}$ If a theory of the first amendment cannot explain very much of existing doctrine, then it is troublesome in two ways. First, it ignores the results reached in real disputes by a wide variety of presumably thought-

53. First Nat'l Bank v. Bellotti, 435 U.S. 765 (1978).

54. See Baker, Realizing Self-Realization, supra note 50; Baker, Commercial Speech: A Problem in the Theory of Freedom, 62 IowA L. REV. 1 (1976). These and other issues relating to communication in a commercial context are discussed in Shiffrin, supra note 52.

55. See Ginzburg v. United States, 383 U.S. 463, 474-75 (1966); New York Times Co. v. Sullivan, 376 U.S. 254, 265-66 (1964). Both of these cases are now better known for other propositions, but both contain clear Supreme Court statements that the presence of the profit motive does not diminish the extent of free speech protection. Such a conclusion entails one of two premises. Either making money is itself a first amendment value, in which case a large range of purely commercial activities would be newly subsumed in first amendment theory, or the New York Times and Ralph Ginzburg were protected solely because of the value of their products to society. The first premise is plainly untenable, and the second takes us out of the realm of speaker-oriented self-expression theories.

56. New York Times Co. v. United States, 403 U.S. 713 (1971) (per curiam).

57. J. RAwLS, A TheORY OF JustiCE 48-51 (1971). 
ful judges. Second, the more doctrine we accumulate the harder it is to discard. Thus a fully satisfactory first amendment theory ought to justify and incorporate a substantial portion of that which cannot realistically be jettisoned. We may want to reevaluate doctrine in light of theory, but we ought also to think seriously about the obligation to reevaluate theory in light of doctrine. And from this perspective it is relevant that time and again in recent cases, speech that relates to matters of public concern is granted special protection. ${ }^{58}$

This theoretical digression has not been without purpose. We must examine closely the implications of deontological self-expression theories because, if vahid, they offer the most promise of divorcing a theory of free speech from a theory of the public interest. If we can sever a theory of free speech from the goal of promoting the general welfare, then strong limitations on inajoritarian input may be justified. If deontological theories undergird the first amendment, they certainly provide no justification for granting particular power over speech to juries or to the public at large, and indeed they even provide reasons for withdrawing control over speech from the public or its representatives. Such theories are unsound, however, for they fail to differentiate a theory of free speech from a theory of general personal liberty, and thus provide neither explanation of the special textual prominence of the free speech clause nor justification for protecting commumication when it causes harm to others. Moreover, self-expression theories generate a range of particular results that seem fundamentally inconsistent with much of contemporary first amendment doctrine. Deontological theories hold out the promise of a way around jury or legislative power, but unfortunately offer little in themselves.

\section{III}

If deontological theories of free speech are fundamentally unsound, then we must revert to consequentialist theories, which draw their ultimate support from what is best for the people. Historically, of course, the leading theory of this variety is that which is variously described under a "search for truth" or "marketplace of ideas" rubric. Here the public interest is the ultimate poimt of reference. This theory argues that, in the long run, people are better off with more truth and inore knowledge than with less, even if in the short run they are all too likely to side with error and folly. Moreover, truth can best be ascertained if all ideas

58. Even putting aside the highly controversial Dun \& Bradstreet, Inc. v. Greenmoss Builders, Inc., 105 S. Ct. 2939 (1985), public or political speech is treated as special in Connick v. Myers, 461 U.S. 138 (1983); NAACP v. Claiborne Hardware Co., 458 U.S. 886 (1982); Brown v. Hartlage, 456 U.S. 45, 53-54 (1982); Citizens Against Rent Control v. City of Berkeley, 454 U.S. 290, 295-300 (1981); Consol. Edison Co. v. Public Service Comm'n, 447 U.S. 530 (1980); Landmark Communications, Inc. v. Virginia, 435 U.S. 829, 838-39 (1978); Gertz v. Robert Welch, Inc., 418 U.S. 323, 339-41 (1974); and New York Times Co. v. Sullivan, 376 U.S. 254, 270 (1964). 
are allowed to compete in the marketplace, with the judgment of history rather than some governmental agency as the arbiter in the arena of ideas. $^{59}$

Search for truth theories are premised on the consequentialist assumption that an open marketplace of ideas will lead to more knowledge and on the utihtarian assumption that more knowledge serves the pubhic welfare. This might suggest that such theories present arguments for greater jury or legislative power. Is not the verdict of a jury or the conclusion of a representative legislature a more accurate reflection of the judgment of the market than the conclusion of a hmited number of self-mterested bureaucrats? But marketplace theory is more sophisticated than that, and the notion of the public marketplace of ideas need not entail granting any particular amount of power to juries or to legislatures. If we begin with the assumption that transient majorities do not always do what is best for society (in an objective, external sense rather than in a preference sense), or even what is best for the majorities themselves, then we can see the first amendment in somewhat of a different hight.

The first amendment, and indeed much of the entire Constitution, is premised on the view that a group of people with remarkable foresight and insight recognized that majorities, swayed by short term passions and short term perceptions of what is good for them, will often make ultimately unwise decisions. To guard against this, the framers and the ratifiers of the first amendment decided ${ }^{60}$ to disable ephemeral majorities from hurting themselves and their heirs by cutting off the search for truth. Under this view, the first amendment is a commitment to future generations not to place too much of their welfare under our control. ${ }^{61}$

This explanation of the first ainendment argues for withdrawing considerable decisional power from juries and legislatures, even when they are seen as surrogates for current popular desires. For it is not today's determination of truth, but the determination of truth in the long run, that is the focal point of the marketplace of ideas theory. Thus, for the people's own good, or if not for their own then for that of their descendents, the first amendment will not let them make certain decisions. The best analogy is perhaps that of a spendthrift trust. Aware of our own weaknesses in times of need, crisis, or passion, we disable our-

59. I discuss marketplace of ideas and search for truth theories more fully in F. SCHAUER, supra note 51, at 15-34. See generally Ingber, The Marketplace of Ideas: A Legitimizing Myth, 1984 DUKE L.J. 1.

60. Although in these sentences I use original intent terminology, the same point can be made in terms of what the first amendment has been taken to mean, or in terms of what it has become, regardless of whether its current meaning was originally intended.

61. See J. Elster, UlysSes ANd THE SiReNS 93-96 (1979); Sunstein, Interest Groups in American Public Law, 38 Stan. L. Rev. 29 (1985). 
selves through the first amendment from making decisions we or posterity might later regret.

The theory of the marketplace of ideas, therefore, has the structural attributes of deontological theories while remaining consequentialist in orientation. Like deontological theories, this variety of consequentialist theory generates rights $\mathrm{m}$ the strong sense, ${ }^{62}$ that is, rights which have the power to resist short-term and even intermediate-term perceptions of maximizing the public interest. If the marketplace of ideas theory is concerned with the the long-run well-being of people regardless of what they think is good for them im the short run, then, like deontological selfexpression theories, it may loosen free speech from the majoritarian shackles it has inherited from Zenger and his contemporaries.

As with self-expression theories, however, the marketplace theory suffers not from its inability to remove free speech determinations from popular control, but from its intrinsic defects as a theory of free speech. The underlying premises of the marketplace of ideas are suspect, as we can see by evaluating the platitudes of the past in light of the realities of the present. Does truth imvariably or even frequently win out when some views are backed by far more dollars than others? While Buckley v. Valeo $^{63}$ and its progeny ${ }^{64}$ may have limited congressional control over campaign spendimg $m$ the name of the first amendment, the cry of "buying an election" is hardly a hollow claim. That individuals and political action committees are allowed by existing first amendment doctrine to freely pour money imto campaigns does not mean that there is in fact no danger of elections bemg bought. Is the entire advertising industry premised on an erroneous view of the world, or is Madison Avenue correct in believing that how and how much you say something is far more imiportant than what you say?

Even if the marketplace of ideas/search for truth theory is taken not to be an absolute guarantee of truth-finding, but rather a comparative judgment about the truth-finding capabilities of the public and a governmental agency or court, the result of the comparison is by no means clear. Is it clear that the risks (especially outside the arena of political speech) of error or bias in governmental deterinination of truth are greater than the risks attending monopoly or oligopoly in the market-

62. On the ability of utilitarianism to generate rights, see generally Lyons, Human Rights and the General Welfare, 6 PHIL. \& PuB. AFF. 113 (1977).

63. 424 U.S. 1 (1976).

64. See, most recently, FEC v. National Conservative Political Action Comm. 105 S. Ct. 1459 (1985). See generally Levinson, Regulating Campaign Activity: The New Road to Contradiction (Book Review), 83 Mich. L. Rev. 939 (1985); Polsby, Buckley v. Valeo: The Special Nature of Political Speech, 1976 SuP. CT. Rev. 1; Powe, Mass Speech and the Newer First Amendment, 1982 SuP. CT. Rev. 243; Wright, Politics and the Constitution: Is Money Speech?, 85 YALE L.J. 1001 (1976). 
place of ideas? This is not the place to explore these issues in depth, but our increasing knowledge about the process of idea transinission, reception, and acceptance makes it more and inore difficult to accept the notion that truth has some inherent power to prevail in the marketplace of ideas, or that the distinction between truth and falsity has much explanatory power in telling us which ideas are likely to be accepted by the public and which are likely to be rejected. ${ }^{65}$

If we are to have a theory of the first amendment that will serve for the first amendment's third century, it is unlikely that the outdated platitudes of the marketplace of ideas will suffice. In addition to the marketplace inodel's dubious empirical and epistemological presuppositions, it too, like theories of self-expression, is becoming increasingly detached from first ainendinent doctrine. Under a marketplace of ideas theory no special prouninence or protection need be given to speech related to public or pohitical matters, since the marketplace decides not only the truth of ideas, but also their importance. Conversely, a standard external to the marketplace is imphicit in any special prominence for public or political speech. But the difficulty comes with the substance of that external standard. Do the reasons for a inarketplace of ideas for public or political speech relate to an independent (not market-deterinined) good in having public determinations of public policy and public value? If, now as inuch as in Zenger's time, public participation in self-government is taken as a transcendent good, this would provide an explanation of much of conteinporary free speech doctrine while freeing free speech theory from the empirical and philosophical problems of other approaches. It seems anomalous however, to beheve that the value of public participation can free us from a commitment to public decisionmaking, and it is to this paradox that I will now turn.

65. I am not making the claim, often made by others (e.g., Ingber, supra note 59, at 25-31) that truth is an inherently subjective or culturally determined concept. Although some truths would undeniably fit this claim, others would not. My argument here is about the ability of the populace to determine objective (which is not the same as certain) truth. I am talking, therefore, about the ability of the public to discern that astrology is false, that cigarettes are harmful to health, and that politicians who claim not to have discussed something have usually discussed it at enormous length. My claim, therefore, although it involves certain philosophical assumptions about truth, is basically an empirical one: that many factors other than truth or falsity determine the extent to which propositions will be accepted or rejected by the public. On the basis for this empirical claim, the locus classicus is probably M. MCLuhan, UNDERSTANDing Media (1964). The empirical assumptions of marketplace theory are also called into question in C. LINDBLOM, PoLrTICS AND Markets (1977); M. Yudof, When Government SPEAKs: Politics, LAW, AND Government EXPRESSION IN AMERICA $71-89$ (1983); Kramer, Marconian Problems, Gutenbergian Remedies: Evaluating the Multiple-Sensory Experience Ad on the Double-Spaced, Typewritten Page, 30 FED. Coм. L.J. 35 (1977). 


\section{IV}

One form of free speech theory commonly taken to justify a special prominence for political or public speecli is premised on a conception of popular sovereignty. Under such a theory, most often associated with the writings of Alexander Meiklejohn, ${ }^{66}$ free speech is a necessary component of a system in which ultimate power resides not with governmental officials but with the people. ${ }^{67}$ If the people are ultimately in control, and are to exercise that control on a continuous and involved basis, then they must have access to all available information without the intervention of self-interested governmental officials. In a system in which the people are sovereign, according to Meiklejohn, it is anomalous for the servants of the people to decide what information and ideas their masters may or may not receive. ${ }^{68}$

Meiklejohn's theory presupposes that the impetus for suppression comes from governmental officials. In that sense Meiklejohn and Zenger were reacting against the same evil-a system of government that treated the governors and not the governed as sovereign, and a system of government in which this relationship was sustained by a systematic denial to the governed of information and ideas challenging that allocation of power. But if the goal that undergirds a Meiklejohnian perspective is the same goal that inspired Zenger and his compatriots-giving power to the people-then popularly inspired or popularly supported sanctions against certain publishers or publications are examples not of a denial of sovereignty but of an exercise of it. If a truly representative jury decides to impose damages on a television network, or if the people by popular referendum wish to stiffen their state's hbel laws, then such exercises of popular prerogative are arguably fully within the tradition of Zenger and the principles that spawned the American Revolution. In more abstract terms, if the people feel that privacy, reputation, gentility in language, and quiet need more protection than is currently provided, does not popular sovereignty in Meiklejohn's sense let them (or us) provide greater protection?

The issue narrows to this: Who should determine the rules concern-

66. A. Meiklejohn, Free Speech and its Relation to Self-Government (1948), reprinted in A. Meiklejohn, Political Freedom: THE Constitutional Powers of the PEOPLE 1-89 (1960); Meiklejohn, The First Amendment is an Absolute, 1961 SUP. CT. REV. 245. See generally BeVier, The First Amendment and Political Speech: An Inquiry into the Substance and Limits of Principle, 30 STAN. L. REv. 299 (1978); Bork, supra note 52; Brennan, The Supreme Court and the Meiklejohn Interpretation of the First Amendment, 79 HARv. L. REv. 1 (1965); Kalven, Mr. Alexander Meiklejohn and the Barenblatt Opinion, 27 U. CHI. L. REv. 315 (1960).

67. This is, of course, the vision of the first amendment that undergirds Professor Sunstein's contribution to this Symposium. Sunstein, Government Control of Information, 74 CALIF. L. REv. 889 (1986).

68. A. Meiklejohn, supra note 66 , at $26-27$, reprinted in A. Meiklejohn, Political Freedom: The Constitutional Powers of the People 27 (1960). 
ing the extent of free speech in a society where the people are considered sovereign? Should the traditional jury function of determining reasonable conduct ${ }^{69}$ or the ability of the people to decide what kind of conınunity they wish, either directly or through legislatures, give way, in the name of sovereignty, to the less representative power of a judge? The question is not merely a question of rule application. It is the broader and nore difficult question of the extent to which majorities should be involved in rule determination as well. Defamation is an example of the difficulty of drawing this distinction, for much of what the rule is to the putatively affected publisher will be a function of what juries are likely to do in application. The issue, put starkly, therefore, is the issue of who makes the rules about what can be said in a society in which the people are taken to be sovereign.

We have inherited froin de Tocqueville and Mill the notion of the "tyranny of the majority." And froin their perspective this phrase was not necessarily paradoxical. If one believes the enipirical presuppositions of the marketplace of ideas model, as did Mill, and if one beheves that attaining more trutl transcends the value of popular decisionmaking, then it follows that free speech is just more important than the values undergirding the concept of popular decisionmaking. In cases in which the majority would control speech, therefore, the value in freeing speech from control simply trumps the value in letting the majority do what it wishes. But this conclusion only follows if free speech is taken to be derived from prior principles, such as the transcendent worth of truth, that are independent of conceptions of sovereignty, democracy, or majoritarianisn1. If free speech is taken, however, as it is by Meiklejohn, to be generated by majoritariamisni, or by popular sovereignty, then the reasons for rejecting controls on popular decisionmaking are themselves supposedly inspired by majoritarianism. Under a Meiklejohnian theory, therefore, we might wish to be especially sensitive to restrictions on political speech by unaccountable government officials. But whether we should be equally concerned with restrictions inspired, supported, and impleniented by the people is far more problematic.

One view supporting restrictions on popular decisionmaking holds that nonniajoritarian agents, such as courts, may occasionally be required to safeguard the true wishes or needs of the majority. In Federalist $51,{ }^{70}$ Hanilton argues that self-interested representation niay result in less representativeness in practice than in theory, and that courts niay occasionally have to fill the gap between representation in design and representation in fact. ${ }^{71}$ And Federalist $10^{72}$ teaches us that majoritarian

69. The classic discussion is in O. Holmes, THE COMMON LAW 98-103 (M. Howe ed. 1963).

70. The Federalist No. 51, at 222-26 (J. Madison) (Thompson \& Homans pubs. 1831).

71. This is also the idea that inspires Dean Ely's notion of "representation-reinforcement." J. 
institutions may be captured by factions. These are legitimate concerns, but it is hardly clear that they are germane to contemporary free speech problems. Concerns that technically majoritarian institutions may not be majoritarian in fact do not seem to ring true in the free speech context, for in many cases restrictions of speech are likely to be what the mass of people actually want. The public's apparent desire to restrict sexually explicit materials, to keep Hare Krishnas out of airports, and to teach newspapers a lesson seems scarcely the product of minority factions or the influence of self-imterested legislators. It is always tempting to dismiss public desire as not representing what the public "really" wants, but such simple solutions are just too simple. If the public wants less speech, we should think seriously about what it means to say, in the name of popular sovereignty, that this is not what the public really wants.

The issues raised by the paradox of sovereignty diminish when we look to pohitically oriented theories of free speech not as dependent on popular sovereignty as is Meiklejohn's. Professor Blasi's "checking value" theory, ${ }^{73}$ for example, recognizes that it is unrealistic to suppose that the people actively deliberate on most questions of public policy. ${ }^{74}$ For him the people retain, both theoretically and in practice, the ability to check the most extreme abuses of government. To do this, he argues, the people must have available the information and opinion to enable them to exercise this checking function. Although he talks of speech as performing the checking function, it is in fact the people, fueled or informed by speech, that do the checking.

But even under this more moderate and realistic view of popular power, the paradox of sovereignty ${ }^{75}$ remams. Even if it is important that people have access to information about goverumental abuses of power in order that they can do something about those abuses, it may be equally important that the people be able to restrict or channel the process of communication in order to serve more effectively the checking function itself. For example, a decision to penalize false (even neghigently false)

Ely, Democracy aNd Distrust (1980). For a critique of the concept of representationreinforcement that is far broader than my position but is consistent with it, see Bork, The Impossibility of Finding Welfare Rights in the Constitution, 1979 WASH. U.L.Q. 695, 698-99.

72. THe Federalist No. 10 (J. Madison) (Thompson \& Homans pubs. 1831).

73. Blasi, The Checking Value in First Amendment Theory, 1977 AM. B. Found. RESEARCH J. 521.

74. Id. at $538-43$.

75. See $1 \mathrm{~K}$. Popper, The OPen Society AND Its ENEmies 123-24, 266 n.6 (5th ed. 1966). It is relatively easy to deal with some of the more extreme forms of this type of paradox, such as whether sovereign people can elect a tyrant. But if the solution-that sovereign power cannot be used to impair the mechanisms of continuing sovereignty-is applicable to every form of governmental process, then it would include anything to do with elections, government organization, or political speech. If this is the case, the solutions to the paradox of sovereignty may be so broad as to make the notion of popular control more formal than real. 
statements about public officials may enhance the checking function by increasing the credibility of statements made about public officials. Kentucky's attempt in Brown v. Hartlage ${ }^{76}$ to deter groundless campaign promises can easily be seen as a way of fostering more rather than less popular input into governmental decisionmaking. Similarly, a decision that would increase the focus of media attention on governmental actions by making it easier to criticize public officials than it is to criticize entertainers or athletes could increase popular control over governmental decisionmaking. ${ }^{77}$ When government power is aligned with media concentration, a decision to grant access to the mass media in order that truly nonmainstream "checkers" could check government power would also serve the people's ends. ${ }^{78}$ Finally, think about a decision to "check" the abuse of power by making it harder for the ims to stay $\mathrm{m},{ }^{79}$ such as imposing special limitations on spending or advertising by incumbents, to counterbalance the privileged access that incumbents have to the mass media, the mails (that is, the franking privilege), and to some public forums. ${ }^{80}$

I chose the previous examples carefully. In assessing the relative merits of clains about the value of speech and clains about the value of reputation it is certainly arguable that the views of a current majority are entitled to substantial weight. So too with the relative merits of the conflicting claims of publicity and privacy, of open discourse and public order, and of speakers and those likely to be offended by that speech. But the examples presented in the previous paragrapli are different and stronger. In each of the preceding examples, popular control is exercised in the name of free speech, or at least in the name of control of government power. If a free speech right derived from the notion of popular control is used to deny that control, something very odd is happening. The question of pervasive popular deliberation, following Meiklejohn, or the question of checking the extreme abuses of governmental power, following Blasi, botl involve questions of how popular control is to be implemented. A variety of decisions about low the public will retain control are involved, and some of those decisions could plausibly be decisions that restrict some speecli under some circuinstances. If this hap-

76. 456 U.S. 45 (1982).

77. See Schauer, Public Figures, 25 WM. \& MARY L. Rev. 905 (1984).

78. See Miami Herald Publishing Co. v. Tornillo, 418 U.S. 241, 247-54 (1974); see also Barron, Access to the Press - A New First Amendment Right, 80 HARv. L. REv. 1641 (1967); Bollinger, Freedom of the Press and Public Access: Toward a Theory of Partial Regulation of the Mass Media, 75 MiCH. L. REV. 1 (1976).

79. See J. ELY, supra note 71, at 106 ("Ins have a way of wanting to make sure the outs stay out.").

80. How often are challengers seen on the reviewing stand at the Fourth of July parade? 
pens, is denial of that power to restrict a check on government or is it in fact a check on the people?

One can approach the problem from a different direction and still reach similar conclusions. Theories of free speech can be divided into those that are positive, stressing the values of speech in achieving certain goals, and theories that are negative, stressing the harmful consequences of regulating speech rather than its intrinsic value. ${ }^{81}$

A negative theory, focusing on the special dangers attending regulation of speech, requires a closer look at the source of the regulation. If that regulation is the self-interested action of the prosecutorial branch of government, the power-preserving action of the executive branch, or the power-justifying action of a board of censors, then negative theories of free speech are properly sensitive to the risks of abuse. In contrast, if the regulation is the result of a representative legislature reflecting the people's desires or the result of a jury reflecting the coininunity's sense of the proper standard of conduct, then judicial concern in the nanie of the first amendment is less justified.

Let ine inake my position clear. My claim is not that there cannot be rights against inajorities, nor that there cannot be judicially enforced constitutional rights and structures that, consistent with the essence of constitutionalism, transcend the passions and perceptions of temporary majorities. I am not arguing against judicial review, nor for a general pohicy of deference to legislative determinations in constitutional adjudication. I am inaking the narrower claim that at times we need theories to clothe the naked words of the Constitution, and that if the otherwise most plausible substantive theory of a particular clause or right rests on the value of popular power, then that theory's effect on short-term majoritarian control must be considered. Within any general conception of judicial review, therefore, however deferential or activist, it may be that certain substantive theories point to greater respect for majoritarian decisions within the relatively narrow anbit of those theories. But we seem to be adopting just such a niajoritarian theory of free speech witlout fully appreciating its implications for jury power or other forms of popular decisionniaking. We rely on notions of popular sovereignty while restricting the people's ability to make any of the important decisions about how our leaders will be controlled. We talk about juries as safeguards in the abstract while devising new ways of guarding from

81. See F. SchaUER, supra note 51, at 80-85; Schauer, supra note 77, at 921-29; Schauer, Must Speech Be Special?, supra note 51, at 1299-1301. Some theories, such as Professor Blasi's, stupra note 73 , stress the value of speech in preventing certain harmful consequences, such as the abuse of governmental power. Under the dichotomy I am suggesting here, this is still a positive theory of free speech because it is premised on something that speech does that other forms of conduct do not do. A true negative theory finds its negatives in the process of regulating speech, rather than in the dangers that speech specially prevents. 
them the things we most value. We utter the standard lines about the "right to know" while ignoring the extent to which "right to know" theory founders on the rocks of the people's rather dehiberate lack of interest in knowing.

I am not making normative claims suggesting that majorities or juries ought to restrict the press in any particular way. Rather, I am raising questions about the extent of jury or majoritarian power in our society, without suggesting answers about what juries and majorities ought to do with that power. Indeed, in the long run, more rehance on majorities may shift the locus of free speech debate away from the courthouse and into the public arena itself. However, by removing majorities from any meaningful input into the consideration of free speech issues, we run the risk that those majorities will cease to see free speech as something they ought to care about. ${ }^{82}$ Regardless of the extent to which a society may be traditionally wedded to constitutionahsm and to its particular constitution, there is something about being governed by the past that inevitably will be hard to swallow. ${ }^{83}$ No matter how much we may revere James Madison and his colleagues, free speech is likely to be more accepted if it is perceived as our choice now rather than their choice two hundred years ago. To say that we ought to pay more attention to juries and majorities does not inevitably mean that there ought to be more restrictions on speech, although I do not deny that, in today's world, such would be the short-term outcome of such a course of action.

I want to summarize where I am to this point. Sticking closely to free speech theory, and not bringing im quite different rights against majorities such as the right to be free from racial discrimination, I have tried to show that deontological theories that treat majoritarian power as largely irrelevant are unsatisfactory, and diverge quite drastically from recent trends in first amendment doctrine. On the other hand, those free speech theories that withstand general theoretical scrutiny and that more or less fit within contemporary first amendment doctrine seem to be trapped within the Zengerian paradox. By relying on popular power, these theories make it difficult to say that majorities are irrelevant when the very question of how much power those majorities should have is what is at stake.

In suggesting that we ought to value popular decisionmaking more with respect to free speech issues, I am mindful of the dangers of valuing

82. See Nagel, How Useful is Judicial Review in Free Speech Cases?, 69 CoRNell L. Rev. 302 (1984). The importance to the sturdiness of free speech principles of public acceptance of both the principles and the application is discussed in Blasi, The Pathological Perspective ald the First Amendment, 85 Colum. L. Rev. 449 (1985), and Schauer, Free Speech and the Demise of the Soapbox (Book Review), 84 Colum. L. Rev. 558, $565-67$ (1984).

83. This is not to deny that references to a respected past can shore up support for currently unpopular principles or applications. See Blasi, supra note 73 , at $625,629,639$. 
it too much. Were we confronted with having to incorporate deference to public decisionmaking into some sort of (preferably three-part) test, the difficulties would be substantial. The existing state of first amendinent doctrine, however, makes it easier to incorporate deference to popular decisionmaking than if we were confronted with incorporating this value into a formulaic test. First amendment doctrine is now enorinously complex, consisting of the selective application of a large number of different principles, standards, and rules not capable of easy or mechanical application. ${ }^{84}$ Despite the best efforts of soine commentators and legions of student note writers, tliere is no simple or unitary "test" to deterinine first amendment protection. No flow-chart or litmus-paper test can tell us clearly wlien tlie first amendment is relevant and when it is not, or wliat first amendment principles to use when. Even when we have decided upon an applicable principle, we are often unsure about the results it commends. There is an enornous diversity of communicative acts and an equally large diversity of governmental justifications for restricting some communicative acts. In order to avoid doctrine that inevitably lags behind reality, we have often chosen to anticipate this diversity by opting for tlie flexibility of general language rather than the precision and predictability of briglit line rules.

In liglit of this justifiable subtlety, complexity, and frequent indeterminacy in contemporary first amendment doctrine, it appears open to us to add one more consideration, whicl would not be dispositive in any given case and would not preclude examination of the full panoply of first amendment factors. I suggest adding a factor that considers in exactly this nondispositive way the presence or absence of a public inspiration or of a realistic public check for a decision to restrict cominunication. Sucli public inspiration or public check would suggest that popularly inposed restrictions on coininunication would be less problematic under the first ainendment than the saine restrictions would be if inspired by governinental officials and not subject to popular control. Thus, for exainple, the presence of a jury verdict, or the presence of a clear statement by a representative legislature, or the presence of a popular referendum directly on the issue might be added to the array of first ainendment considerations. In looking at a first amendment case, it ouglit to matter that the decision to impose sanctions was inade by a jury rather than by a bureaucrat accountable to no one. ${ }^{85}$ It ought to matter that a legislature made a decision rather than a police officer. It ought to

84. See Schauer, Codifying the First Amendment: New York v. Ferber, 1982 SuP. CT. REv. 285; Shiffrin, Defamatory Non-Media Speech and First Amendment Methodology, 25 UCLA L. REV. 915 (1978).

85. This may explain, for example, prior restraint doctrine better than it is explained by factors relating to the timing of the restraint. See Blasi, Toward a Theory of Prior Restraint: The Central Linkage, 66 MINN. L. REV. 11 (1981). 
matter that the people by referendum were directly involved in the decision. It ought to matter, as in Zenger itself, that a jury has the power to say, in effect, "Now you've gone too far."

In no case would the factor I urge here likely be dispositive, and thus the suggestion that courts take into account the presence of popular input is neither saying nor asking very much. But in an age of first amendment complexity, it is hard to justify excluding popular inputs as we increasingly rely on popular power to provide the theoretical foundations for the first amendinent. By treating public involvement as a factor, we will not do drastic violence to the modern first amendment, but we will properly take into account an aspect of what John Peter Zenger fought for that has been unfortunately neglected.

\section{V}

Although I have offered a mild corrective to the neglect of the people by traditional free speech theory, I want still to explore, more tentatively, the even broader theoretical issues that lurk around this question. It may be a mistake to assume that political theories of the first amendment must necessarily make ultimate recourse to popular power. Thus I question botli the approach of Meiklejohn, who with his town meeting model $^{86}$ assumed that the people should always be involved, and that of Blasi, who with his Vietnam and Watergate archetypes ${ }^{87}$ assumes that the people are involved at the extremes. Certainly at many times the people are involved. Town meetings really do matter in New England, and popular outcry undemiably contributed to policy changes in Vietnam and personnel changes after Watergate. Identifying or relying on such examples of actual popular control may, however, be theoretically unnecessary. There are cases in which media pressure has served to check public officials despite the lack of any significant broad-based public outcry. Misinformed, misguided, intemperate, or even crooked public officials may enjoy a good measure of popular support; yet their ouster may provide the best answer for the long-run stability of the government, despite the electorate's desire that they remain. Contemporary American government is far too complex to suppose that bad public officials are forced out of office, or forced to change conduct, simply as a result of popular outcry. It may be that the requirements of a stable government, and our notions of what constitutes a "good" government, are only loosely tied to what is desired by the governed. Moreover, conteinporary politics are too complex to suppose that the fear of rejection at the polls or any other form of popular accountability can explain mucl of why public officials

86. A. Meiklejohn, supra note 66 , at 22-23, reprinted in A. Meiklejohn, Polttical Freedom: The Constitutional Powers of the People 24-25 (1960).

87. Blasi, supra note 73 , at 524-27. 
dislike seeing their misdeeds portrayed on the front pages of the daily newspapers.

In place of some of the simplistic assumptions about fear of public political reaction, we ought to explore the full complex of psychological and sociological factors that influence human behavior in general, and official behavior in particular. Think, for example, about the phenomenon of embarrasment. I venture that most people will react to publication of their misdeeds if they feel ashamed, regardless of any specific consequences, such as lack of reelection, that may be likely to occur. If this is the case, then the threat of exposure is likely to inhibit official misdeeds, even without fear of adverse consequences at the polls. If I spill wime on my shirt at a dimner party, or if I teach a class with my fly open, I am hikely to feel embarrased, or humiliated, or mortified, even though no one is likely to think less of me because I have committed one of these perfectly normal social gaffes. Yet the desire to avoid the embarrasment is still likely to influence my future behavior. It seems quite plausible that similar psychological dynamics may be at work with respect to the behavior of governmental officials. The comparatively unconstrained exposure of official conduct may decrease misdeeds apart from any strong connection with electoral power. It may be that encouraging exposure can be justified as a means toward better government, where "better" is defined without reference to what kind of government people might want at a particular moment.

In addition to embarrassment and other psychological phenomena, open scrutimy of official conduct serves another important function apart from informmg the public: it provides necessary information to other public officials. As government becomes increasingly dispersed, a system of checks and balances might need an adjunct mechanism by which one part of government can find out what the other parts are doing. No doubt most federal officials learn more from the Washington Post than from the Federal Register. It is quite possible that as government gets more cumbersome we need the press to tell the left hand what the right hand is doing.

These views are speculative, but they are intended to point inquiry about the governmental or political foundations of free speech in a different direction. We need a free speech theory not only for the age of bureaucracy but also for a society in which most people are astonishingly passive with respect to government. If we are to claim that ultimate power resides with the people, then we must accept the people's right not to care. But if in the long run, it is thought objectively undesirable to allow a passive public to have too much influence over the structure of government, for fear that this passive public will only discover its folly when it is too late, then we have to explore different theoretical and 
empirical explanations for a modern first amendment. Instead of increasingly hollow appeals to the public's right or need to know, such a theory might recognize that a system of open commentary on the qualifications and official conduct of public officials is simply the best way to run a government and the best way to guard against governmental abuse.

In terms of either popular or jury control, an outlook such as this would bring with it freedom from any particular responsibility to incorporate public decisionmaking into free speech doctrine. Such a theory would be frankly paternalistic, forcing values upon the public without regard to public acceptance of those values. This is an uncomfortable thing to admit, and perhaps this discomfort is reflected in the contmuing rehearsal of "right to know" rhetoric even in the face of moreasingly clear and frequent signals from the public that they are not all that interested in knowing what the press wants to tell them.

This discomfort is also reflected in the eagerness with which people desire to dissociate "deniocracy" from "majoritarianism," or to rely on "antecedent" conceptions of democracy not themselves determined by the people. I am not sure I know what is neant by such a move. If it ineans only that majorities ought not to be allowed to ahenate their own political liberties, then the claim is plausible but narrow. It fails to address public attempts to restrict sexually explicit speech in the name of decency, public attempts to protect soap opera stars from the ravages of the tabloids, or public attempts to restrict the activities of religious proselytizers. More often the claim is broader, involving removing from majoritarian control more tlian merely the mechanisnis of majoritarianism. If this is the clain, then it is difficult to understand what "democracy" means for those making this claim. For if it means tliat something is in the best interests of tlie people in the long run whetler they know it or not, then this version of "deinocracy" is hardly differentiated from any other form of government. Even the most totalitarian of governments purport to be acting in the best interests of the people, and sometimes may even accomplish that goal.

What seens to be taking place by references to "democracy" in tliis nonmajoritarian sense is the desire to hook onto the positive enrotive associations of the word "democracy," without regard to whether the people's desires are actually reflected in the process. It may be a good idea to renove certain decisions from the people, but I find it more straightforward to recognize that such views involve less democracy than to try to force an attenuated distinction between majoritarianisn democracy. I think there are decisions that simply ought not to be taken in a democratic manner, and thus the ideal government may involve some mix of democratic and nondemocratic decisionmaking processes.

My reference to "paternalism," therefore, is intentionally provoca- 
tive, designed to rescue serious discussions of the virtues of antimajoritarianism in sone contexts from the murkiness of claims that such antimajoritariamsm is "really" deniocratic. If the people are to be prevented from banning Carnal Knowledge ${ }^{88}$ in the name of local cominunity control over sexual morahity-as well they should be preventedit cannot be in the name of deniocracy, and it cannot be in the name of representation-reinforceinent. We ought to recognize that popular control over nonpolitical speech nuay in some circumstances be a bad idea and address directly just why this is so. Perhaps it is time to face up to the paternalism of the first amendnient, and maybe much of the rest of the Constitution as well. Iniplicit in the Constitition generally, and in the first amendinent in particular, is the fact that a system of government has essentially been forced on us, and there is little we can do about it. But the one that was forced on us has happened to work, and perhaps it is now appropriate to develop the sophistication that will enable us to recognize the paternalisn imphicit in the first amendment, while at the same time we count our blessings for it.

88. Jenkins v. Georgia, 418 U.S. 153 (1974). 